\title{
Methods of Extending the Life Cycle of a TI-100A Boiler
}

\author{
Stepan Lys ${ }^{1}$, Oksana Yurasova ${ }^{1}$, Nadiya Lashkovska ${ }^{1}$ \\ 1. Department of Heat Engineering and Thermal and Nuclear Power Plants, Lviv Polytechnic National University, \\ UKRAINE, 12, S. Bandery Street, Lviv, E-mail: lysss@ukr.net.
}

\begin{abstract}
Reconditioning of the TI-100A boiler can be implemented via a number of engineering solutions, including a complete replacement of the heating surface of the primary and secondary steam superheating circuits, boiler drum replacement, pulverized coal system closing, installation of gas-tight water walls.
\end{abstract}

Keywords: boiler; boiler life cycle; boiler reconditioning; power generating unit manoeuvring, tubular air heater.

\section{Introduction}

In Ukraine there are thirty-six large thermal power stations and cogeneration plants, most of which were built in the last century [1]. The major capacities of Ukraine's TPSs were launched in the $60-80 \mathrm{~s}$ of the $20^{\text {th }}$ century, using the then-available technical solutions. The majority of the power-plant boilers are outmoded. The boiler unit of the power generating unit 10 of Burshtyn TPS, which was put into operation in 1969, is no exception. In 1990, the power capacity of the generating unit was changed to $195 \mathrm{MW}$ and as of 01/01/2016 the unit had operated for 300,614 hrs. From the start of the unit 10, six major overhauls have been done. After the last overhaul the unit 10 has worked over 73,000 hrs.

Therefore, the reconditioning of the boiler units that have run its life cycle is a topical task. When selecting a modernization design, it is important to take into account the possibilities of installing new equipment in the existing boiler units [2], minimization of reconditioning costs while achieving the maximum affect, possibilities of carrying out the reconditioning and further maintenance.

With a view of extending their life cycle, boiler units are reconditioned and modernized through quality repairs, replacement and restoration of the most important worn-out and used-up parts and subassemblies of the units themselves and the steam pipelines.

The methods used for extending the life cycle of a boiler unit, increasing

\section{Presentation of the main material}

A modernized boiler unit must comply with the safety requirements [3] listed in The Electrical Installations Design Regulations, standard GOST 12.2.003-91, Industrial Equipment.

Life cycle. After the reconditioning, the total calculated service life of the elements, parts and subassemblies of a boiler and its auxiliary equipment should be at least 15 years [4] except for fastwearing elements of the equipment. The calculated life cycle of the boiler pressure elements, with the calculated temperature and respective creep flow range, should be

- at least 100,000 hours for the heating surfaces' pipes, outlet chambers of the superheaters and other pipes being heated, as well as for the water economizer;

- at least 200,000 hours for non-heated parts and elements;

- at least 40,000 hours for TAH and spacing elements.

Reliability requirements. A high service reliability of the equipment is required $[4,5]$. 
Maintenance and repair of the equipment must comply with the requirements stated in the regulatory document GKD 34.20.661-2003, Regulations for Organization of Technical Maintenance and Repair of Electrical Power Plants and Networks' Facilities.

The repair cycle, types and duration of the boiler repair must conform to the below benchmarks:

- The workover interval for the boiler must be no less than 8,000 hours;

- The mean time of the boiler unit operation between two major overhauls must not be less than 40,000 hours;

- The duration of minor repairs of the boiler unit is to be $263 \mathrm{hrs}$./year (13 days/year).

- The duration of an average repair is not to exceed 25 days (one repair per four years).

- The duration of a major repair must be 48 days (one repair per six years).

The availability factor of the boiler unit and auxiliary equipment must not be less than $92.02 \%$.

Manoeuvrability requirements. The power generating unit must be able to operate in the manoeuvring mode, i.e. to be involved in the primary and secondary regulation of the frequency and power in the normal and emergency duty cycles of the Ukrainian electrical grid [1-3]. For boiler units operation, a compliance with the load regulation range limits and lower and upper range values must be ensured. The lower range value for the power generating unit's load must be established on the condition of ensuring the constant complement of the operating equipment and reliability of the water wall system operation and automatic regulation system within all the specified load ranges without involving the staff. The boiler is supposed to operate within the load range of $50-100 \%$ of the rated value without using fuel (gas, heavy oil) for flame stabilization. It is necessary to ensure extending the lower limit of the operating range of regulating the power generating unit load up to 50\% when burning the solid fuel without using the back-up fuel and liquid slag removal taking into account the expected manoeuvring mode of the power generating unit under the rated pressure of the boiler without using back-up fuel and emergency injections.

The expected technical indicators of the boiler running on the certified fuel [3-5] (the lower range value of the load) are presented below.

Based on the liquid slag output:

- Without putting out the upper-level burners - 65\%;

- Putting out the upper-level burners $-50 \%$.

Based on the condition that the parameters of the steam beyond the boiler are preserved (without putting out the upper-level burners):

- For excess air at the outlet of the furnace $1.2-80 \%$;

- For excess air at the outlet of the furnace $1.33-70 \%$;

- For excess air at the outlet of the furnace $1.61-50 \%$.

Liquid slag removal without using the backup fuel falls within the range 50-100\% of the expected rated load of the power generating unit of $210 \mathrm{MW}$ (which is approved in advance). The minimum heat load of the boiler on the rated parameters without back-up fuel must ensure the minimum electrical load of 50\% (105 MW) of the rated load of the power generating unit equal to 210 MW [6]. For operation on coal without using the backup fuel, the steam rate based on the primary steam is $640 \mathrm{t} /$ hour. The minimum steam rate based on the primary steam is $\mathrm{t} / \mathrm{hour}$ (for operation on coal without using the backup fuel and power generating unit load $105 \mathrm{MW}$ ). There should be provisions for an option of the minimum safe output for the power generating unit operation, for which it is allowable to change the complement of the running equipment and to 
switch off some of the automatic regulators. At the lower range value of the load or minimum safe output, it is permissible to reduce the temperature of the main steam down to $25^{\circ} \mathrm{C}$. After the reconditioning, the boiler should be able to ensure the power generating unit operation on the sliding parameters.

\section{The results of researching}

Technical solutions for modernizing the boiler unit, its internal mechanical part, electrical part, regulation and control system must be based on a modern high-tech bug-free gas cleaning technology, the service reliability of which has been proved over time with respective quality and efficiency guarantees $[5,6]$.

The boiler unit consists of a one-drum boiler with the steam rate of $640 \mathrm{t} / \mathrm{hr}$. with natural circulation and T-configuration, with steam superheating, equipped with the furnace with liquid

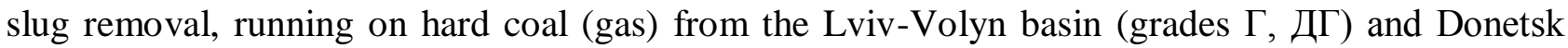
basin (grades Г, ГСШ, ГМСИІ, ДСШ, ДСМШ).

The main feature of the steam boiler is the combustion chamber located in the middle part and the heat-recovery surfaces and control stage of the resuperheater located in the two vertical downtakes to the left and to the right of the furnace chamber for the bidirectional gas exhausting [5, 7]. Both downtakes are connected with the furnace chamber by the sloping exhaust conduits in which the convection heating surfaces of the primary and secondary superheaters are located. In each of the downtakes, down the way of the gas, there is the control stage of the secondary superheater, second stage of the tubular air heater, water economizer, first stage of the tubular air heater (dual-in-line) and electric heater.

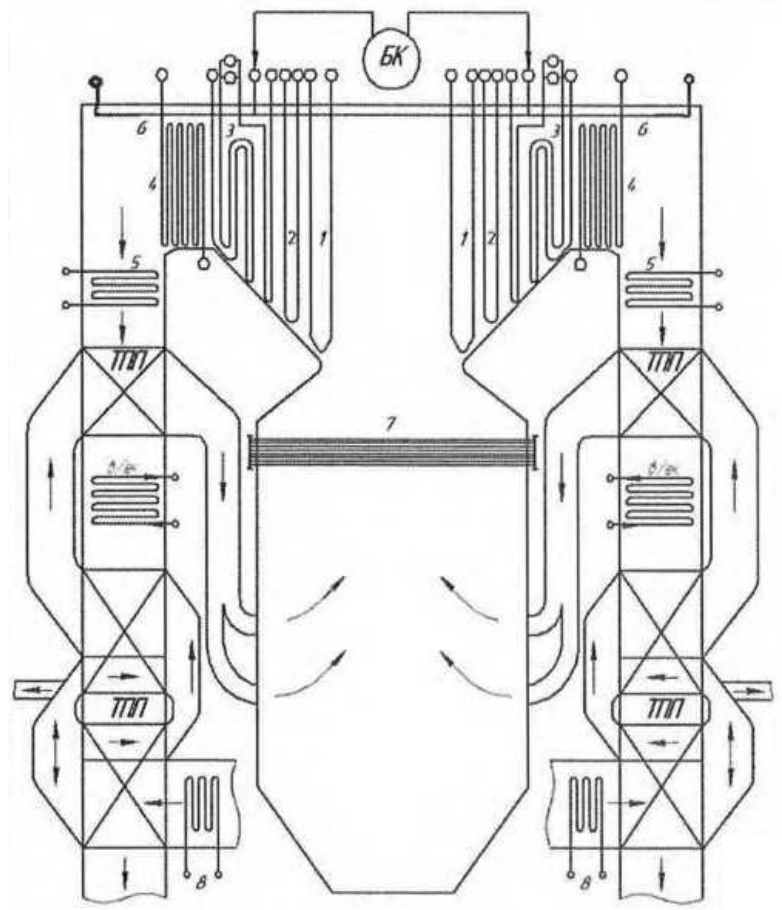

Fig.1. Schematic circuit diagram of the air-gas flow path for the power generating unit 10 of the boiler ТП-100A: 1 - platen superheater; 2 - primary hot convection superheater; 3 - secondary superheater; 4 - primary cold convection superheater; 5 - control stage of the secondary superheater; 6 - ceiling superheater; 7 - wall radiator superheater; 8 - electric air heater. 
Approximately $50 \%$ of the pipes of the side waterwalls in the lower part of the ledge are forkconnected to the vertical sections, into which part of the passing steam-water mixture branches [6, 7]. In the upper part of the ledges, both straight and bent sections of the pipes are included into the pick-up boxes, from where the steam-water mixture is diverted into the drum through the heating pipes made of the steel 12X1MФ with the diameter of $133 \times 10 \mathrm{~mm}$.

A principally new system of feeding (transportation) of the high-concentration pulverized coal under dilution (HCPCd) using steam ejectors has been proposed instead of the conventional system of transportation of the high-concentration pulverized coal from the pulverized-coal feeder to the burners by the pneumatic conveyor system under the pressure of the forced-flow fan, and the calculated speeds at the burner outlet are: secondary air $-25-30 \mathrm{~m} / \mathrm{s}$; gas-air mixture for pulverized coal transportation by the mill fan- $25-28 \mathrm{~m} / \mathrm{s}$; coal-air mixture for pulverized coal transportation HCPCd - 18-20 m/s.

In the straight-flow burner, into the primary air branch pipe, the pipe having the diameter of $377 \mathrm{~mm}$, through which primary air and pulverized coal mixture passes (discharge of the used, dustloaded drier (gas-air mixture) by the one-fan closed coal pulverization system), a steam ejection burner device is installed. This is a $133 \times 9 \mathrm{~mm}$ pipe, at whose end entering the furnace there is an adjutage - an impeller made of stainless steel ensuring wide-cone flow of the primary air/pulverized coal/steam mixture and effective aerodynamic mixing with the secondary air.

The secondary air is fed into the prism-shaped case of the straight-flow burner. The highconcentration pulverized coal is conveyed into the burner under the dilution of the steam ejector, and the scheme itself was called HCPCd [7]. The steam injector creates regulated dilution from the pulverized-coal feeders to the burner sufficient for effective transportation of the pulverized coal with the concentration of $50 \mathrm{~kg}$ pulverized coal $/ 1 \mathrm{~kg}$ air. The pulverized coal from the feeder gets into the mixing device with the air intake windows (the transport agent being the air of the main building), where the moving pulp is formed, which goes along the pulverized-coal duct having the diameter of $89 \times 4.5 \mathrm{~mm}$ with the calculated speed $5-8 \mathrm{~m} / \mathrm{s}$. The ejector gets the steam from the cold resuperheating line with the pressure reduced from 1.0+1.4 MPa, with the back-up from the crossstation line $2.5 \mathrm{MPa}\left(25 \mathrm{~kg} / \mathrm{cm}^{2}\right)$. An important feature of the scheme HCPCd is the pulverized-coal conduits equipped with simple and effective anti-blocking protection. It is based on measuring the dilution differential at the mixing device. Upon reducing this value to the protection set point (200$300 \mathrm{~Pa}$ ), the pulverized-coal feeder switches off and the pulverized-coal conduits are blown through. When the differential is restored, the pulverized-coal feeder automatically switches on.

The flat-flame burners of the power generating unit 10 boiler form a flat horizontal flame due to the fact that the coal-air mixture current and secondary air current encounter each other at an angle. Prior to feeding the air to the burners, it is heated at the two stages of the tubular air heater. Before the first stage tanks of the air heater, the electrical heating device is installed.

At each secondary air conduit, each burner is fitted with a control damper, whose function is to set up the necessary air consumption in the furnace, while burning different types of fuel.

The drum steam-cooling device consists of the upper and lower distribution headers. The drum steam cooling has two functions:

- «intake» (valves are opened from the working boilers) for steam intake into the system;

- «cooling» (valves are opened on the boiler that is being cooled in order to feed the steam for steam cooling of the drum top from the rest of the working boilers). 
Main calculated technical characteristics of the boiler

\begin{tabular}{|c|c|c|}
\hline Parameter & Design value & $\begin{array}{l}\text { Value after } \\
\text { reconditioning }\end{array}$ \\
\hline Rated steam rate, $\mathrm{t} /$ hour & 640 & 640 \\
\hline Working pressure in the drum, $\mathrm{kgf} / \mathrm{cm}^{2}$ & 155 & 155 \\
\hline $\begin{array}{l}\text { Working parameters of the live steam beyond the boiler*: } \\
\text { - pressure, } \mathrm{kgf} / \mathrm{cm}^{2} \\
\text { - temperature, }{ }^{\circ} \mathrm{C}\end{array}$ & $\begin{array}{l}140 \\
570\end{array}$ & $\begin{array}{l}140 \\
545\end{array}$ \\
\hline Rated steam flow consumption in the resuperheater, $t /$ hour & 560 & 560 \\
\hline $\begin{array}{c}\text { Input working parameters of the superheated steam } \\
\text { for the rated steam flow consumption: } \\
\text { - pressure, } \mathrm{kgf} / \mathrm{cm}^{2} \\
\text { - temperature, }{ }^{\circ} \mathrm{C}\end{array}$ & $\begin{array}{c}24.0 \\
340\end{array}$ & $\begin{array}{l}27.6 \\
324\end{array}$ \\
\hline $\begin{array}{l}\text { Output working parameters of the superheated steam } \\
\text { for the rated steam flow consumption: } \\
\text { - pressure, } \mathrm{kgf} / \mathrm{cm}^{2} \\
\text { - temperature, }{ }^{\circ} \mathrm{C}\end{array}$ & $\begin{array}{l}22.3 \\
570\end{array}$ & $\begin{array}{l}25.1 \\
545\end{array}$ \\
\hline Pressure loss in the resuperheating path, $\%$ & & 9 \\
\hline $\begin{array}{l}\text { Temperature of the feed water at the rated steam flow, }{ }^{\circ} \mathrm{C} \\
\text { consumption, }{ }^{\circ} \mathrm{C}\end{array}$ & 235 & 245.6 \\
\hline Calculated temperature of the cold air, ${ }^{\circ} \mathrm{C}$ & 30 & 30 \\
\hline Temperature of the hot air at the rated steam rate, ${ }^{\circ} \mathrm{C}$ & 390 & 390 \\
\hline Calculated output-input ratio for the rated steam rate, $\%$ & 90 & 90 \\
\hline $\begin{array}{l}\text { Regulation range for the steam rate without using back-up } \\
\text { fuel and maintaining the temperature of the live team and } \\
\text { secondary steam at } 545^{\circ} \mathrm{C} \text { without injection, } t / \text { hour }\end{array}$ & & $298-640$ \\
\hline
\end{tabular}

As, according to the plan, after the reconditioning the power generating unit is supposed to reach $210 \mathrm{MW}$, and under this load the steam consumption will be $595 \mathrm{t} /$ hour per turbine without the auxiliary steam consumption, the lower range limit of the boiler regulation should be calculated for the steam rate of 298 t/hour, which corresponds to the power generating unit capacity of 105 MW.

\section{Conclusion}

A number of technical solutions for the reconditioning of the TП-100A boiler unit have been proposed, including: 1) a complete replacement of the heating surface of the primary and secondary steam superheating circuits; 2) replacement of the boiler drum; 3) pulverized coal system closing; 4) installation of gas-tight water walls; 5) replacement of all the tanks of the water economizer; 6) replacement of all the TAH tanks; 7) replacement of the check and control valves; 8) replacement of all the steam pipelines in a boiler room. 
In addition to extending the life cycle of the boiler, they will result in an increase in the outputinput ratio of at least $2 \%$ and significantly enhance the manoeuvrability of the power generating unit as a whole.

The pulverized coal system closing will make it possible to avoid the discharge of the pulverized coal onto the electrostatic precipitators, thereby reducing the fuel consumption for electric power generation. The installation of gas-tight water walls provides for decreasing the cold air inflow into the furnace, which will have a positive effect on the output-input ratio and liquid slag output, while the replacement of all the tanks of the water economizer and air heater enables heating the feed water and, respectively, the cold air to the calculated value (before the reconstruction, the temperatures did not reach the calculated value). The check and control valves replacement provides for quality regulation of the main parameters of the steam, the pressure and temperature, with an increased speed of the power generating unit manoeuvring and reduced overburning of the fuel during the manoeuvring.

Therefore, reconditioning of the ТП-100A boiler enables raising the rated electric capacity of the power generating unit to the value no less than $210 \mathrm{MW}$ without increasing the live steam consumption, enhancing the technical and economic indices of the equipment operation, renewing the steam service life of the boiler elements, raising the output-input ration to at least $90 \%$, as well as extending the life cycle of the boiler elements, boiler pipes, steam pipelines, non-replaceable pressure vessels to at least 40,000 hours.

\section{References}

[1] Sigal, I.Ya. Analysis of the Ukrainian boiler economy with the view to modernization, life cycle extension or replacement of low- and medium capacity boilers. / I.Ya. Sigal, E.P. Dombrovska, A.V. Smukhina et. al. // Energy Technologies \& Resource Saving Journal. - 2003. - No6. - pp. 76-79. in Ukrainian

[2] Korchevoy, Yu.P. Boiler industry as an essential element of power engineering development / Yu.P. Korchevoy, A.Yu. Maistrenko, N.I. Dunayevska, A.A. Potapov // Power Engineering and Electrification Journal. - 2004. - No12. - pp. 7-9. in Ukrainian

[3] Korchevoy, Yu.P. Methods of modernization and reconditioning of pulverized coal boiler units for thermal power stations / Yu.P. Korchevoy, A.Yu. Maistrenko, I.A. Volchyn // Novyny Energetyky Journal. - 2000. - No4. - pp. 38-40. in Ukrainian

[4] Yanko, P.I. Operation modes of power-generating boilers. Monograph. / P.I. Yanko, Y.S. Mysak. - Lviv: Ukrainian Technologies Publishers, 2004 - 271 p. in Ukrainian

[5] Operation and Maintenance of Zakhidenergo OJSC TPS power-generating equipment. Edited by Omelianovskyi, P.Y., Mysak, Y.S. Ukrainian Technologies Publishers, 2005 - 410 p. in Ukrainian

[6] Dneprov Ю.B. Installation of low- and medium capacity boiler units / Yu.V. Dneprov, D.N. Smirnov, M.S. Feistein. - Moscow: Vysshaya Shkola Publishers, 1980. - 334 p.in Russian

[7] Mikhailov V.E. Results from expert tests of the TP-100A boiler at the Lugansk thermal power station during the combustion of lean coal and anthracite culm with addition of RA-GEN-F anaklarid / Mikhailov V.E., Tupitsyn S.P., Sokolov V.V., Chebakova G.F., Malygin V.I., Yazykov Yu.V., Kharchenko A.V., Chetverikov A.N. // Thermal Engineering. - 2012. - V. 59. No8. - pp. 573-579. 